\title{
Early therapeutic experience with the endothelin antagonist BQ-123 in pulmonary hypertension after congenital heart surgery
}

\author{
B Prendergast, D E Newby, L E Wilson, D J Webb, P S Mankad
}

\begin{abstract}
Objective-To assess the effect of endothelin type $A\left(\mathrm{ET}_{\mathrm{A}}\right)$ receptor antagonism in infants with pulmonary hypertension following corrective surgery for congenital heart disease.

Design-Open label, preliminary study.
\end{abstract} Setting-Tertiary paediatric cardiothoracic surgical centre.

Patients-Three infants (aged 3 weeks, 7 weeks, and 8 months) with postoperative pulmonary hypertension unresponsive to conventional treatment, including inhaled nitric oxide.

Interventions-Patients received incremental intravenous infusions $(0.1$ to 0.3 $\mathrm{mg} / \mathrm{kg} / \mathrm{h}$ ) of the $\mathrm{ET}_{\mathrm{A}}$ receptor antagonist BQ-123.

Main outcome measures-The response to BQ-123 administration was determined using continuous invasive monitoring of cardiorespiratory variables.

Results-BQ-123 infusion caused a reduction in the ratio of pulmonary to systemic pressures $(0.62(0.01)$ to $0.52(0.03)$, mean (SEM)) with an accompanying decrease in right ventricular stroke work index (4.6 $(0.4)$ to $2.5(0.3) \mathrm{g} / \mathrm{m})$ and a tendency for the cardiac index to rise $(2.1(0.2)$ to 2.7 $\left.(0.6) 1 / \mathrm{min} / \mathrm{kg} / \mathrm{m}^{2}\right)$. This was associated with a well tolerated fall in the arterial partial pressure of oxygen (16.5 (4.1) to $12.4(3.3) \mathrm{kPa}$ ) and mean systemic arterial pressure (57 (3) to 39 (3) $\mathrm{mm} \mathrm{Hg}$ ).

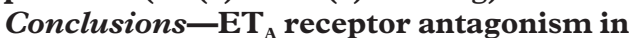
infants with postoperative pulmonary hypertension after corrective surgery for congenital heart disease led to significant improvement in pulmonary haemodynamic indices. However, these benefits were associated with reductions in systemic blood pressure and arterial oxygen saturation, the latter consistent with a ventilation-perfusion mismatch. On the basis of these results, studies in pulmonary hypertension will need to proceed with caution.

(Heart 1999;82:505-508)

Keywords: endothelin-1; pulmonary hypertension; receptor antagonism; congenital heart disease

Postoperative pulmonary hypertension is a common clinical problem following successful surgical correction of congenital heart defects and may lead to significant morbidity and mortality. ${ }^{1}$ Its occurrence relates both to pre-existing pulmonary hypertension and the acute effects of surgery and cardiopulmonary bypass. Dysfunction of the pulmonary vascular endothelium appears to be a major contributing factor for the development of pulmonary hypertension in this group of patients.

Endothelin-1 is an extremely potent endothelium derived vasoconstrictor peptide ${ }^{2}$ which is released and cleared in the pulmonary circulation. $^{3} \quad$ Plasma concentrations of endothelin-1 are increased in subjects going to high altitude, ${ }^{4}$ in patients with chronic heart failure, ${ }^{5}$ and in patients with pulmonary hypertension. ${ }^{6}$ Moreover, in these conditions, the degree of pulmonary hypertension and pulmonary vascular resistance correlates closely with plasma endothelin-1 concentrations. $^{4-6}$ Children with pulmonary hypertension $^{7}$ and persistent pulmonary hypertension of the newborn ${ }^{8}$ also have raised plasma endothelin-1 concentrations that correlate with disease severity, ${ }^{8}$ are particularly marked after cardiopulmonary bypass, ${ }^{9}$ and may play a role in its pathogenesis. ${ }^{10}$

Studies in animal models of pulmonary hypertension have reported reversal of pulmonary hypertension with endothelin receptor antagonists ${ }^{112}$ and endothelin converting enzyme inhibition. ${ }^{13}$ Indeed, in a sheep model of pulmonary hypertension induced by aortopulmonary shunting in utero, endothelin antagonism eliminated the postoperative increase in pulmonary vascular resistance following cardiopulmonary bypass. ${ }^{14}$ Reddy and colleagues ${ }^{14}$ concluded that endothelin antagonism warrants further study in children at risk of pulmonary hypertension after surgical repair with cardiopulmonary bypass. There have been no published clinical studies to date assessing the therapeutic benefits of endothelin antagonism in postoperative pulmonary hypertension.

We report our preliminary experience with the therapeutic use of the endothelin type $\mathrm{A}$ $\left(\mathrm{ET}_{\mathrm{A}}\right)$ receptor antagonist, $\mathrm{BQ}-123$, in three infants with postoperative pulmonary hypertension following corrective surgery for congenital heart disease.

\section{Methods}

Written informed parental consent was obtained for each child and the study was approved by the local research ethics committee.

BQ-123 (American Peptide Company, Sunnyvale, California, USA) was given under a Department of Health (UK) Doctors and Dentists Exemption Certificate. 
Table 1 Patient characteristics

\begin{tabular}{|c|c|c|c|c|c|c|}
\hline Patient & $\begin{array}{l}\text { Age } \\
\text { (weeks) }\end{array}$ & Sex & $\begin{array}{l}\text { Weight } \\
(g)\end{array}$ & Diagnosis & Procedure & Inotropes and vasodilators \\
\hline 1 & 3 & Female & 3100 & $\begin{array}{l}\text { Anomalous aortic origin of left } \\
\text { pulmonary artery, patent foramen ovale, } \\
\text { persistent arterial duct }\end{array}$ & $\begin{array}{l}\text { Mobilisation of left pulmonary artery } \\
\text { with formation of pulmonary artery } \\
\text { bifurcation, closure of patent foramen } \\
\text { ovale, division of persistent arterial duct }\end{array}$ & Dopamine $3 \mu \mathrm{g} / \mathrm{kg} / \mathrm{min}$ \\
\hline 2 & 7 & Male & 3500 & $\begin{array}{l}\text { Obstructed partial anomalous } \\
\text { pulmonary venous drainage, left } \\
\text { pulmonary artery stenosis, atrial septal } \\
\text { defect }\end{array}$ & $\begin{array}{l}\text { Right pulmonary vein to right atrium } \\
\text { anastamosis, atrial diverting patch, left } \\
\text { pulmonary artery patch }\end{array}$ & $\begin{array}{l}\text { Dobutamine } 20 \mu \mathrm{g} / \mathrm{kg} / \mathrm{min} \\
\text { Glyceryl trinitrate } 2 \mathrm{mg} / \mathrm{kg} / \mathrm{min}\end{array}$ \\
\hline 3 & 25 & Female & 6100 & $\begin{array}{l}\text { Ventricular septal defect, persistent } \\
\text { arterial duct (Aicardi and Poland } \\
\text { syndromes) }\end{array}$ & $\begin{array}{l}\text { Patch closure of ventricular septal defect, } \\
\text { closure of persistent arterial duct }\end{array}$ & $\begin{array}{l}\text { Dobutamine } 20 \mu \mathrm{g} / \mathrm{kg} / \mathrm{min} \\
\text { Dopamine } 3 \mu \mathrm{g} / \mathrm{kg} / \mathrm{min}\end{array}$ \\
\hline
\end{tabular}

The three infants (aged 3 weeks, 7 weeks, and 8 months) were anaesthetised according to our standard protocol. Phenoxybenzamine (1 $\mathrm{mg} / \mathrm{kg}$ ) was given before establishing cardiopulmonary bypass. Corrective surgery was performed after inducing systemic hypothermia and cold crystalloid cardioplegic arrest. A thermodilution pulmonary artery flow catheter (3 F; Baxter Health Care, Thetford, UK) and a left atrial line were inserted before discontinuing cardiopulmonary bypass.

After chest closure, the infants were returned to the intensive care unit and maintained on a standard regimen of vecuronium $(0.1 \mathrm{mg} / \mathrm{kg} /$
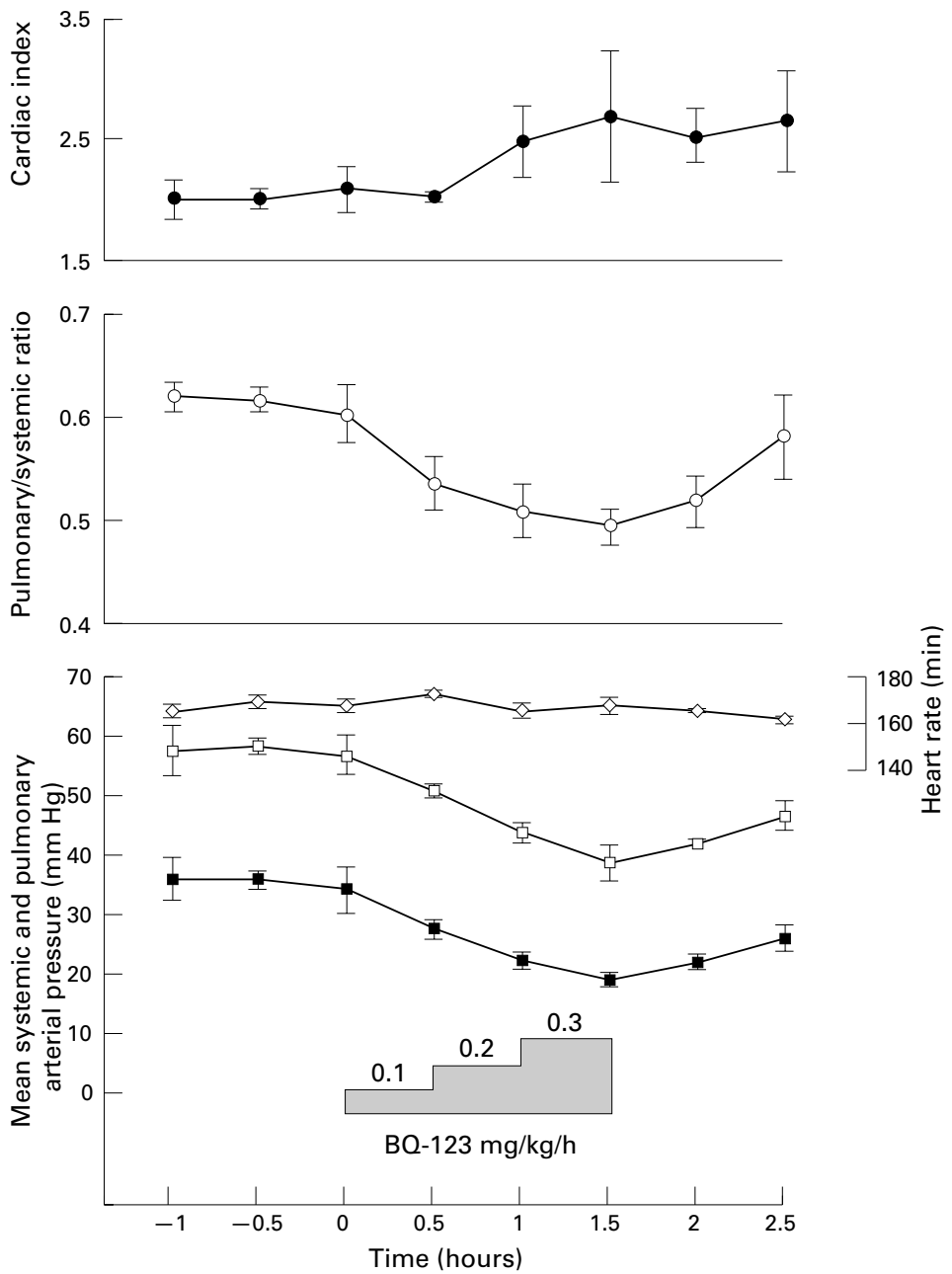

Figure 1 Effect of BQ-123 (0.1 to $0.3 \mathrm{mg} / \mathrm{kg} / \mathrm{min})$ on cardiac index (•), pulmonary/systemic ratio $(0)$, heart rate $(\diamond)$, and mean systemic ( $\square$ ) and pulmonary ( $(\square)$ arterial pressure in infants with postoperative pulmonary hypertension following corrective surgery for congenital heart disease. (Error bars are SEM, $n=3$.) h), fentanyl $(5.0 \mu \mathrm{g} / \mathrm{kg} / \mathrm{h})$, and midazolam (0.1 $\mathrm{mg} / \mathrm{kg} / \mathrm{h}$ ). Following rewarming, the ratio of pulmonary to systemic arterial pressure $(\mathrm{P} / \mathrm{S}$ ratio) was determined using invasive monitoring. Infants were entered into the study if they did not have a residual left to right shunt on echocardiography and had a $\mathrm{P} / \mathrm{S}$ ratio greater than 0.5 which did not respond to standard treatment, including inhaled nitric oxide (10 ppm increasing to 20,30 , and $40 \mathrm{ppm}$ for 30 minutes at each dose). During the study period, the amount of sedation and inotropic support was maintained constant and atrial pressures kept stable using packed red blood cells or human albumin solution. Following stabilisation for three hours, BQ-123 was dissolved in $0.9 \%$ saline and given intravenously at $0.1,0.2$, and $0.3 \mathrm{mg} / \mathrm{kg} / \mathrm{h}$, for 30 minutes at each dose.

Data are presented as mean (SEM). Haemodynamic variables were measured in triplicate at each time point and the mean taken. Recognising the small sample size and inherent variation between haemodynamic variables, nonparametric analyses (Wilcoxon rank sum) were used to compare variables before, during, and after BQ-123 infusion. Statistical significance was assumed at the $5 \%$ level.

\section{Results}

Characteristics of the patients are shown in table 1.

Baseline left and right atrial pressures were 9.6 (1.2) and $7.3(0.3) \mathrm{mm} \mathrm{Hg}$, respectively, and did not change during or after BQ-123 infusion. However, the $\mathrm{P} / \mathrm{S}$ ratio fell in all patients during BQ-123 administration ( $\mathrm{p}<0.001$; fig 1 ) and returned to baseline about 90 minutes after discontinuation of the infusion. Concomitant with the changes in the $\mathrm{P} / \mathrm{S}$ ratio, the systemic arterial pressure fell (fig 1), although the fall was proportionately less than for the pulmonary arterial pressure and was well tolerated. Right ventricular stroke work index mirrored the changes in $\mathrm{P} / \mathrm{S}$ ratio and fell significantly in response to $\mathrm{BQ}-123$ infusion, from $4.56(0.31)$ to 2.90 (1.90) g. $\mathrm{m} / \mathrm{m}^{2}(\mathrm{p}<0.001)$. The cardiac index tended to increase and left ventricular stroke work index fell from $8.0(0.9)$ to $6.2(0.9) \mathrm{g} . \mathrm{m} / \mathrm{m}^{2}$ $(\mathrm{p}<0.001)$ but there were no changes in heart rate, acid-base balance, or urine output.

Despite haemodynamic improvements, the arterial partial pressure of oxygen fell in all three infants during BQ-123 infusion, from 16.5 (4.1) to 12.4 (3.3) $\mathrm{kPa}$. Because of the 
reduction in arterial oxygen partial pressures, nitric oxide $(20 \mathrm{ppm})$ was reintroduced into the ventilatory circuit of two infants two hours after starting the BQ-123 infusion (patients 1 and 3 ). Both infants then responded promptly to nitric oxide administration, with the partial pressures rising from 7.4 to $8.2 \mathrm{kPa}$ and from 8.4 to $10.5 \mathrm{kPa}$. The third infant (patient 2) did not receive inhaled nitric oxide because in that infant the partial pressure of oxygen was 18.6 $\mathrm{kPa}$ at its nadir. Qualitatively, this did not appear to correlate with cardiopulmonary bypass time.

No adverse effects were seen on withdrawal of BQ-123 and all three infants survived to the 30th postoperative day.

\section{Discussion}

Although potentially life threatening, postoperative pulmonary hypertension following corrective surgery for congenital heart disease is usually reversible. When conventional treatment, including inhaled nitric oxide, fails further measures such as extracorporeal circulatory support and membrane oxygenation may be required. We have conducted the first preliminary study to examine the therapeutic effects of $\mathrm{ET}_{\mathrm{A}}$ receptor antagonism under such circumstances. Although we were able to show a significant improvement in pulmonary haemodynamic indices, this was associated with arterial hypoxaemia and systemic hypotension.

Endothelin-1 is continuously released by the endothelium and contributes to the maintenance of basal vascular tone ${ }^{1516}$ and blood pressure..$^{17}{ }^{18}$ It is therefore not surprising that BQ-123 caused a reduction in systemic as well as pulmonary arterial pressure and this is consistent with the haemodynamic effects seen with the acute administration of BQ-123 in patients with heart failure. ${ }^{19}$ However, in these three infants, $\mathrm{ET}_{\mathrm{A}}$ receptor antagonism appeared to be more selective for the pulmonary vascular bed, with a proportionately greater effect in comparison with the systemic circulation. This suggests that endothelin-1 provides a greater contribution to the maintenance of vascular tone in the pulmonary circulation in postoperative pulmonary hypertension.

In animal models of pulmonary hypertension induced by aortopulmonary shunting, not only have raised plasma endothelin-1 concentrations been found, but also an increased pulmonary vasoconstrictor response to endothelin-1 infusion. ${ }^{20}$ These findings may, in part, relate to the upregulation of endothelin-1 and endothelin converting enzyme expression, as well as the 10-fold downregulation of the $\mathrm{ET}_{\mathrm{B}}$ receptor within the pulmonary vasculature. ${ }^{21}$ The balance of receptor expression is therefore largely shifted to the vasoconstrictor $\mathrm{ET}_{\mathrm{A}}$ receptor and this may exacerbate the pulmonary hypertension. Thus it would be anticipated that selective $\mathrm{ET}_{\mathrm{A}}$ receptor antagonism would produce a greater reduction in pulmonary vascular resistance than combined $\mathrm{ET}_{\mathrm{A}}$ and $\mathrm{ET}_{\mathrm{B}}$ receptor antagonism.
A degree of systemic hypotension and impaired oxygenation is the inevitable consequence of effective systemic vasodilatation and these are the limiting factors in the clinical use of conventional agents. Intrapulmonary ventilation/perfusion matching is dependent upon local hypoxic vasoconstrictive reflexes and so is impaired by pulmonary vasodilatation. Although they were initially unresponsive to inhaled nitric oxide, improved oxygenation was seen in the two patients who received inhaled nitric oxide $(20 \mathrm{ppm})$ after $\mathrm{ET}_{\mathrm{A}}$ receptor antagonism. This effect may be related to the recently described improvement in pulmonary vascular responsiveness to nitric oxide following $\mathrm{ET}_{\mathrm{A}}$ receptor antagonism. ${ }^{22}$ The mechanisms of this effect remain to be established, but in an animal model of pulmonary hypertension, $\mathrm{ET}_{\mathrm{A}}$ receptor antagonism was associated with both an improvement in endothelium dependent vasodilatation and an increase in pulmonary vascular smooth muscle sensitivity to nitric oxide. ${ }^{22}$

This first preliminary report of the use of $\mathrm{ET}_{\mathrm{A}}$ receptor antagonism in infants with postoperative pulmonary hypertension following corrective surgery for congenital heart disease suggests an improvement in the pulmonary to systemic ratio and right ventricular strokework index. However, these benefits were counterbalanced by potentially adverse reductions in arterial oxygenation and systemic blood pressure. These findings suggest that endothelin antagonism, particularly in combination with inhaled nitric oxide, may represent a valuable new approach to the treatment of refractory postoperative pulmonary hypertension which merits further but cautious investigation.

We thank Dr M J Godman for funding the study through the Calderwood Research Endowment Fund. DEN was the recipient of a British Heart Foundation Junior Research Fellowship (FS/95009). DJW is supported by a Research Leave Fellowship from the Wellcome Trust (WT 0526330).

1 Bando K, Turrentine MW, Sharp TG, et al. Pulmonary hypertension after operations for congenital heart disease: hypertension after operations for congenital heart disease: Cardiovasc Surg 1996;112:1600-9.

2 Gray GA, Webb DJ. The endothelin system and its potential as a therapeutic target in cardiovascular disease. Pharmacol Ther 1996;72:109-48.

3 Dupuis J, Stewart DJ, Cernacek P, et al. Human pulmonary circulation is an important site for both clearance and production of endothelin-1. Circulation 1996;94:1578-84.

4 Goerre S, Wenk M, Bartsch P, et al. Endothelin-1 in pulmonary hypertension associated with high-altitude exposure. Circulation 1995;91:359-64.

5 Cody RJ, Haas GJ, Binkley PF, et al. Plasma endothelin correlates with the extent of pulmonary hypertension in patients with chronic congestive heart failure. Circulation 1992;85:504-9.

6 Cacoub P, Dorent R, Nataf P, et al. Endothelin-1 in the lungs of patients with pulmonary hypertension. Cardiovasc Res 1997;33:196-200.

7 Allen SW, Chatfield BA, Koppenhafer SA, et al. Circulating immunoreactive endothelin-1 in children with pulmonary hypertension: association with acute hypoxic pulmonary reactivity. Am Rev Respir Dis 1993;148:519-22.

8 Kumar P, Kazzi NJ, Shankaran S. Plasma immunoreactive endothelin-1 concentrations in infants with persistent pulmonary hypertension of the newborn. Am F Perinatol 1996; 13:335-42.

9 Komai H, Adatia IT, Elliot MJ, et al. Increased plasma levels of endothelin-1 after cardiopulmonary bypass in patients with pulmonary hypertension and congenital heart patients with pulmonary hypertension and congenit

10 Abman SH. Pathogenesis and treatment of neonatal and postnatal pulmonary hypertension. Curr Opin Pediatr 1994; 6:239-47. 
11 DiCarlo VS, Chen SJ, Meng QC, et al. $\mathrm{ET}_{\mathrm{A}}$-receptor antagonist prevents and reverses chronic hypoxia-induced pulmo-

nary hypertens

2 Prié S, Leung TK, Cernacek P, et al. The orally active ET receptor antagonist (+)-(S)-2-(4,6-dimethoxy-pyrimidin-
2-yloxy)-3-methoxy-3,3-diphenyl-proprionic acid (LU 135252) prevents the development of pulmonary hypertension and endothelial metabolic dysfunction in monocrotaline-treated rats. F Pharmacol Exp Ther 1997; 282:1312-18

13 Kirshbom PM, Tsui SSL, DiBernardo LR, et al. Blockade of endothelin-converting enzyme reduces pulmonary hypertension after cardiopulmonary bypass and circulatory arrest. Surgery 1995;118:440-5.

14 Reddy VM, Hendricks-Munoz KD, Rajasinghe HA, et al. Post-cardiopulmonary bypass pulmonary hypertension in lambs with increased pulmonary blood flow: a role for endothelin-1. Circulation 1997;95:1054-61.

15 Haynes WG, Webb DJ. Contribution of endogenous generation of endothelin-1 to basal vascular tone in man. Lancet 1994;344:852-4.

16 Berrazeuta JP, Bhagat K, Vallance P, et al. Dose- and timedependency of the vasodilator effects of the endothelin antagonist, BQ-123, in the human forearm. Br F Clin Phar macol 1997;44:569-71.
17 Haynes WG, Ferro CJ, O'Kane KPJ, et al. Systemic endothelin receptor blockade decreases peripheral vascular resistance and blood pressure in humans. Circulation 1996: 93:1860-70.

18 Krum H, Viskoper RJ, Lacourciere Y, et al. The effect of an endothelin-receptor antagonist, bosentan, on blood pressure in patients with essential hypertension. $N$ Engl f Med 1998;338:784-90.

19 Cowburn PJ, Cleland JGF, McArthur JD, et al. Short term haemodynamic effects of BQ-123, a selective endothelin ET-receptor antagonist, in chronic heart failure. Lancet 1998;352:201-2.

20 Wong J, Reddy VM, Hendricks-Munoz KD, et al. Endothelin-1 vasoactive responses in lambs with pulmonary hypertension and increased pulmonary flow. $A m \mathcal{F}$ Physiol 1995;269:H1965-72.

21 Black S, Fineman J, Johengen M, et al. Increased pulmonary flow alters the molecular regulation of vascular reactivity in the lamb [abstract]. Chest 1998;114:39S.

22 Prié S, Stewart DJ, Dupuis J. Endothelin receptor blockade improves nitric oxide-mediated vasodilatation in monocrotaline-induced pulmonary hypertension. Circulation 1998;97:2169-74. 